\title{
Fe-binding organic ligands in coastal and frontal regions of the western Antarctic Peninsula
}

\author{
Indah Ardiningsih ${ }^{1}$, Kyyas Seyitmuhammedov ${ }^{2}$, Sylvia G. Sander ${ }^{3}$, Claudine H. Stirling ${ }^{2}$, Gert-Jan Reichart ${ }^{1,4}$, \\ Kevin R. Arrigo ${ }^{5}$, Loes J. A. Gerringa ${ }^{1}$, and Rob Middag ${ }^{1,2}$ \\ ${ }^{1}$ Department of Ocean Systems, NIOZ Royal Netherlands Institute for Sea Research and Utrecht University, Texel, 1797SH, \\ the Netherlands \\ ${ }^{2}$ Centre for Trace Element Analysis and Chemistry Department, University of Otago, Dunedin, New Zealand \\ ${ }^{3}$ International Atomic Energy Agency, 4a Quai Antoine 1er, 98000, Principality of Monaco, Monaco \\ ${ }^{4}$ Faculty of Geosciences, Earth Sciences Department, Utrecht University, Utrecht, 3512JE, the Netherlands \\ ${ }^{5}$ Department of Earth System Science, Stanford University, USA
}

Correspondence: Indah Ardiningsih (Indah.ardiningsih@nioz.nl)

Received: 26 September 2020 - Discussion started: 18 November 2020

Revised: 1 March 2021 - Accepted: 6 April 2021 - Published: 11 August 2021

\begin{abstract}
Organic ligands are a key factor determining the availability of dissolved iron (DFe) in the high-nutrient lowchlorophyll (HNLC) areas of the Southern Ocean. In this study, organic speciation of Fe is investigated along a natural gradient of the western Antarctic Peninsula, from an ice-covered shelf to the open ocean. An electrochemical approach, competitive ligand exchange - adsorptive cathodic stripping voltammetry (CLE-AdCSV), was applied. Our results indicated that organic ligands in the surface water on the shelf are associated with ice-algal exudates, possibly combined with melting of sea ice. Organic ligands in the deeper shelf water are supplied via the resuspension of slope or shelf sediments. Further offshore, organic ligands are most likely related to the development of phytoplankton blooms in open ocean waters. On the shelf, total ligand concentrations ( $\left[L_{\mathrm{t}}\right]$ ) were between 1.2 and $6.4 \mathrm{nM}$ eq. Fe. The organic ligands offshore ranged between 1.0 and $3.0 \mathrm{nM}$ eq. Fe. The southern boundary of the Antarctic Circumpolar Current (SB ACC) separated the organic ligands on the shelf from bloomassociated ligands offshore. Overall, organic ligand concentrations always exceeded DFe concentrations (excess ligand concentration, $\left[L^{\prime}\right]=0.8-5.0 \mathrm{nM}$ eq. Fe). The $\left[L^{\prime}\right]$ made up to $80 \%$ of $\left[L_{\mathrm{t}}\right]$, suggesting that any additional $\mathrm{Fe}$ input can be stabilized in the dissolved form via organic complexation. The denser modified Circumpolar Deep Water (mCDW) on the shelf showed the highest complexation capacity of $\mathrm{Fe}$ ( $\alpha_{\mathrm{Fe}{ }^{\prime} \mathrm{L}}$; the product of $\left[L^{\prime}\right]$ and conditional binding strength
\end{abstract}

of ligands, $\left.K_{\mathrm{Fe}, \mathrm{L}}^{\mathrm{cond}}\right)$. Since $\mathrm{Fe}$ is also supplied by shelf sediments and glacial discharge, the high complexation capacity over the shelf can keep Fe dissolved and available for local primary productivity later in the season upon sea-ice melting.

\section{Introduction}

The Southern Ocean is a high-nutrient low-chlorophyll (HNLC; e.g., Sunda et al., 1989) region where the phytoplankton biomass is relatively low despite high ambient macronutrient concentrations, i.e., nitrogen $(\mathrm{N})$, phosphorus (P) and silicon (Si) (e.g., Martin et al., 1991; Schoffman et al., 2016). The generally limited availability of light and the micronutrient iron $(\mathrm{Fe})$ prevents phytoplankton from depleting $\mathrm{P}$ and $\mathrm{N}$ in the vast majority of HNLC areas (de Baar et al., 2005; de Baar, 1990; Martin et al., 1991; Viljoen et al., 2018). Indeed, Fe regulates the dynamics of primary production as it is involved in various cellular processes (Schoffman et al., 2016; Sunda, 1989). In the HNLC Southern Ocean, the availability of Fe has a direct impact on the early spring phytoplankton bloom and thus on primary productivity (Moore et al., 2013). The Fe limitation in the Southern Ocean could thus have a direct effect on the amount of atmospheric $\mathrm{CO}_{2}$ sequestration (Le Quéré et al., 2016; Arrigo et al., 2008; Raven and Falkowski, 1999) to the deep ocean via the biological pump (De La Rocha, 2006; Lam et al., 2011). Ac- 
cordingly, the availability of Fe in the Southern Ocean is not only important for sustaining the food web, but it also has a substantial impact on global climate (Henley et al., 2019 and references therein).

The low solubility of $\mathrm{Fe}$ in seawater, coupled with low atmospheric and terrestrial input of $\mathrm{Fe}$, results in the scarcity of dissolved $\mathrm{Fe}$ (DFe) in the Southern Ocean. In oxygenated seawater, $\mathrm{Fe}$ is mainly present in its oxidized form, $\mathrm{Fe}(\mathrm{III})$, predominantly as $\mathrm{Fe}(\mathrm{III})$ oxy-hydroxide species. These species tend to undergo further hydrolysis (Liu and Millero, 2002) and are thereby removed from the water column by scavenging or precipitation processes. Organic Fe-binding ligands greatly elevate Fe solubility in seawater (Kuma et al., 1996) by stabilizing $\mathrm{Fe}$ in Fe-ligand complexes, thus allowing Fe to remain longer in the water column. Moreover, Fe bound to organic ligands appears to be bioavailable to marine phytoplankton (Maldonado et al., 2005; Rijkenberg et al., 2008; Hassler et al., 2020). As such, organic ligands are a key component of Fe chemistry and bioavailability, notably in HNLC regions, as illustrated by Lauderdale et al. (2020). These authors showed, with an idealized biogeochemical model of the ocean, that the interaction between microbial ligand production and the binding of $\mathrm{Fe}$ by these ligands functions as a positive feedback to maintain the DFe standing stock in the oceans.

Different ligand types exist with characteristics (i.e., binding strength) that are probably related to their origin. The characteristics of organic ligands can be measured by the competition against well-characterized artificial ligands with known stability constants. An analysis is done using an electrochemical technique, competitive ligand exchange (CLE) - adsorptive cathodic stripping voltammetry (AdCSV; CLEAdCSV). The application of AdCSV gives the total concentration $\left(\left[L_{\mathrm{t}}\right]\right)$ and conditional binding strength $\left(K_{\mathrm{Fe} \text { e } \mathrm{L}}^{\text {cond }}\right)$ of the dissolved organic ligands but does not provide information on the identity of ligands. Even though the exact compositions and origins of Fe-binding ligands are still largely unknown, $\left[L_{\mathrm{t}}\right]$ and $K_{\mathrm{Fe} \text { ' } \mathrm{L}}^{\text {cond }}$ obtained by CLE-AdCSV, together with ancillary data, can be used to infer potential sources of these organic ligands. The organic ligands in seawater either have a terrestrial or marine source. The terrestrialsourced ligands are supplied from lithogenic and pedogenic inputs found within the boundary region between land and sea (i.e., coastal seas and estuaries) (Buck and Bruland, 2007; Batchelli et al., 2010; Kondo et al., 2007; Buck et al., 2007; Bundy et al., 2015; Gerringa et al., 2007; Laglera and van den Berg, 2009).

The marine organic ligands come from in situ biological activities, being either actively produced or passively generated through microbial activity. Laboratory studies have documented the active production of Fe-binging ligands under Fe-limited conditions (Boiteau et al., 2013, 2016; Butler, 2005). Several types of siderophores, low-molecular-weight organic compounds which have a strong affinity for Fe, are produced by mixed marine bacteria communities under $\mathrm{Fe}$ stress (Butler, 2005), suggesting that high ligand concentrations are related to a mechanism of $\mathrm{Fe}$ acquisition in an Fe-limited environment. These compounds have also been extracted (Boiteau et al., 2016; Macrellis et al., 2001; Velasquez et al., 2011) or identified (Mawji et al., 2008; Velasquez et al., 2016) in field samples. However, they generally occur at picomolar levels (Boiteau et al., 2019) and are a small contributor to the total ligand pool. Other ligand types, such as polysaccharide compounds, are passively generated in situ from microbial excretion and grazing (Sato et al., 2007; Laglera et al., 2019b). The polysaccharides, such as exopolymeric substances (EPSs), are excreted abundantly by a large number of microbial cells, especially in surface water covered by sea ice (Norman et al., 2015; Lannuzel et al., 2015). Although EPSs are relatively labile macromolecules, they can be present in up to micromolar concentrations in seawater, showing the potential to outcompete stronger binding siderophores (Hassler et al., 2017). In addition, humic or humic-like substances (HSs) from various origins constitute another type of ligand (Krachler et al., 2015; Laglera et al., 2019a; Whitby et al., 2020). Typically, HSs are derived from the remineralization and degradation of organic matter (Burkhardt et al., 2014). Terrestrial input of organic matter can supply HSs to estuarine and coastal areas, whereas sediment resuspension and upwelling often supply HSs to the continental shelf (Gerringa et al., 2008; Buck et al., 2017). HSs have also been shown to be part of Fe-binding ligands in biologically refractory deep ocean dissolved organic matter (rDOM) with low Fe bioavailability. However, photodegradation of rDOM was shown to increase the Fe bioavailability making Fe bound to such substances an important source in HNLC areas where upwelling plays a role (Hassler et al., 2020; Lauderdale et al., 2020; Whitby et al., 2020; Laglera et al., 2019a).

The Bellingshausen Sea along the western Antarctic Peninsula (WAP) region has a distinct natural DFe gradient (Sherrell et al., 2018; Moffat and Meredith, 2018). The hydrography is strongly influenced by the dynamics of shelfocean water exchange. The shoreward intrusion of Circumpolar Deep Water (CDW) provides macronutrients for the shelf region, whereas offshore-flowing waters supply the micronutrients $\mathrm{Fe}$ and $\mathrm{Mn}$ to the open ocean from local sources (De Jong et al., 2015; Sherrell et al., 2018), such as glacial meltwater, sediments and upwelling. The shelf sea of the WAP is a biologically rich marine ecosystem in the Southern Ocean. The abundance, community composition and trophic structure of marine primary producers are directly impacted by the changing ice conditions and longer periods of open water due to climate change (Turner et al., 2013). Moreover, rapid increases in anthropogenic $\mathrm{CO}_{2}$ has enhanced the airsea $\mathrm{CO}_{2}$ fluxes, decreasing the bulk seawater $\mathrm{pH}$, resulting in ocean acidification (Mikaloff Fletcher et al., 2006), which alters the physicochemical properties of seawater and impacts the organic complexation of $\mathrm{Fe}$ (Ye et al., 2020). As the WAP has undergone significant warming (Turner et al., 2020), the 
changes in ice conditions will influence the supply of $\mathrm{Fe}$ and organic ligands, shaping the net primary production in this region. Understanding the sources and distribution of organic ligands provides important information on DFe availability, which is a fundamental step towards understanding the impact of the warming of the Antarctic region on primary productivity in the Southern Ocean.

In this study, surface waters were sampled in a region of mixing between shelf-influenced waters and HNLC waters in the Bellingshausen Sea along the WAP. The CLE-AdCSV technique was used to quantify the total concentrations and conditional stability constants of Fe-binding ligands. These parameters were used to examine the distribution of the organic ligands and to assess their potential sources and influence on the mobilization of $\mathrm{Fe}$ in a transect from ice-covered shelf waters to the open ocean of the Antarctic zone.

\section{Material and methods}

\subsection{Sample collection}

Samples were collected on board the R/V Nathaniel B. Palmer (Cruise NBP1409) during the austral spring between 31 October and 21 November 2014 in the Bellingshausen Sea (Arrigo et al., 2017) west of the Antarctic Peninsula (Fig. 1). Water samples were obtained from the surface to a maximum of $600 \mathrm{~m}$ depth at five stations along a transect extending from Adelaide Island on the shelf out into the Bellingshausen Sea in a northwest direction (Fig. 1). Stations A (70) and B (72) are situated near the shore in the shelf sea, Station C (96) is located at the continental shelf break, and stations D (84) and E (90) are located offshore over deep waters. These stations are a subset of those occupied during the cruise. Hereafter, for simplicity the alphabetical scheme of station numbers will be used, in which station A is closest to the coast and station $\mathrm{E}$ is furthest from the coast.

Hydrographic parameters were measured using a conventional conductivity-temperature-depth (CTD) rosette equipped with a fluorometer (WET Labs ECO-AFL/FL) and an oxygen sensor (SBE-43). Seawater samples for DFe and Fe-binding ligands in this study were obtained using $12 \mathrm{~L}$ GO-FLO bottles attached to a Kevlar ${ }^{\circledR}$ wire. Seawater samples were filtered over $0.2 \mu \mathrm{m}$ filters (cellulose acetate, Sartobran 300 , Sartorius ${ }^{\circledR}$ ) into pre-cleaned sample bottles inside a trace metal clean van. Sample bottles were pre-cleaned following a three-step cleaning protocol for trace element sample bottles (Middag et al., 2009).

Filtered seawater samples for Fe-binding ligand analysis were collected into acid-cleaned $500 \mathrm{~mL}$ low-density polyethylene (LDPE; Nalgene) bottles and stored at $-20^{\circ} \mathrm{C}$ immediately after collection. For DFe analysis, filtered seawater was collected into acid-cleaned $60 \mathrm{~mL}$ LDPE (Nalgene) bottles and acidified to a $\mathrm{pH}$ of 1.8 with concentrated quartz-distilled hydrochloric acid $(\mathrm{HCl})$ to give a final con- centration of $0.024 \mathrm{M} \mathrm{HCl}$. Filtered samples for macronutrient concentration analysis were stored at $-20^{\circ} \mathrm{C}$ (for $\mathrm{N} \mathrm{sam}$ ples) and at $4{ }^{\circ} \mathrm{C}$ (for Si samples).

\subsection{Analysis of DFe and nutrients}

The DFe analysis is described in detail by Seyitmuhammedov et al. (2021). In short, the DFe analysis was conducted using high-resolution inductively coupled plasma mass spectrometry (HR-ICP-MS) using a Thermo Fisher Element XR instrument at the Royal Netherlands Institute for Sea Research (NIOZ), the Netherlands, and using an Ametek Nu Attom instrument at the University of Otago, New Zealand. Samples were UV radiated and pre-concentrated using an automated seaFAST system (SC-4 DX seaFAST-pico; ESI) equipped with Nobias chelate PA1 resin. The quantification was done via standard additions to low-trace-metal seawater. The recovery of the resin was $\sim 100 \%$ and was verified in every analytical run by a comparison between the slope of the seawater calibration curve and an eluent acid calibration curve based on Biller and Bruland (2012). Accuracy and reproducibility were monitored by regular measurements of the reference materials SAFe D1 and GEOTRACES South Pacific (GSP) seawater and an in-house reference seawater sample, North Atlantic Deep Water (NADW). Results for DFe analyses of reference samples were $0.72 \pm 0.01$ $\mathrm{nM}(n=3$; NIOZ $)$ and $0.73 \pm 0.02 \mathrm{nM}(n=6$; University of Otago) for SAFe D1 2013 (May 2013 consensus value $=0.69 \pm 0.04 \mathrm{nM})$ and $0.15 \pm 0.01 \mathrm{nM}(n=13$; NIOZ) for GSP 2019 (consensus value $=0.16 \pm 0.045 \mathrm{nM}$ ). The average overall method blank (seaFAST and ICP-MS), determined by repeatedly measuring acidified ultrapure water in every analytical run as a sample, was $0.05 \pm 0.02 \mathrm{nM}$ $(n=21)$. The limit of detection was $0.05 \mathrm{nM}$, obtained as 3 times the standard deviation of the blank.

Macronutrients $(\mathrm{N}$ and $\mathrm{Si}$ ) were analyzed simultaneously with a discrete TRAACS-800 autoanalyzer (Technicon) in the shore-based laboratory at NIOZ.

\subsection{Analysis of Fe-binding ligands}

Samples were thawed in the dark and vigorously shaken prior to further treatment. Electrochemical analysis CLE-AdCSV with salicylaldoxime (SA) as an added competing ligand (Abualhaija and van den Berg, 2014) was used. In short, the voltammetric system consisted of a BioAnalytical Systems (BASi) controlled growth mercury electrode connected to an Epsilon 2 analyzer (BASi). The voltammetric system was controlled using ECDSoft interface software. The electrodes in the voltammetric stand included a standard Hg drop working electrode, a platinum wire counter electrode and a double-junction $\mathrm{Ag} / \mathrm{AgCl}$ reference electrode $(3 \mathrm{M} \mathrm{KCl})$.

For the titration, $10 \mathrm{~mL}$ sample aliquots were added to 12 pre-conditioned Teflon (fluorinated ethylene propylene, FEP; Savillex) vials and buffered to a seawater $\mathrm{pH}$ of 8.2 with 


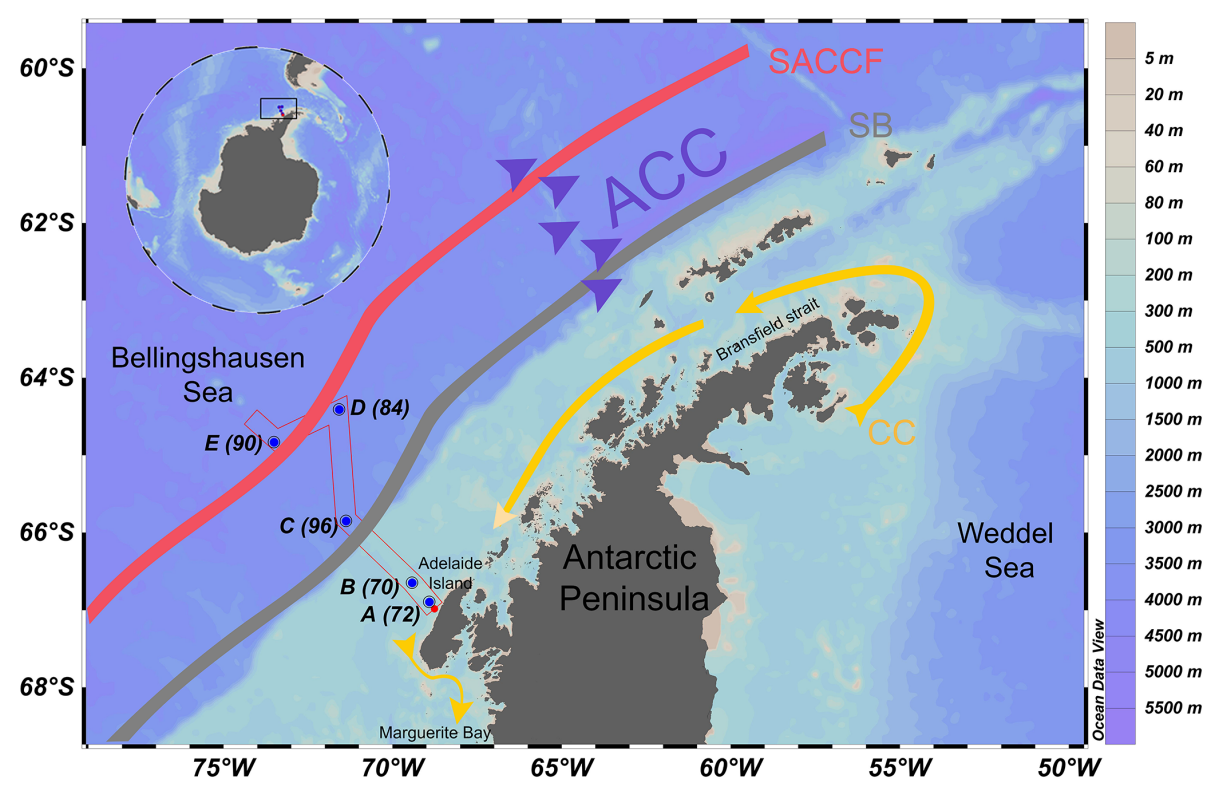

Figure 1. Map of the sampling sites along our study transect near the western Antarctic Peninsula. The stations are indicated by blue dots and station numbers. The Antarctic Circumpolar Current (ACC) is indicated by purple arrows. The coastal current (CC) is indicated by a yellow arrow. The southern boundary (SB) of the ACC front is indicated by the grey line. The southern ACC front (SACCF) is indicated by the red line. See Fig. 6 in Arrigo et al. (2017) for details on the ACC flow path.

$0.1 \mathrm{M}$ ammonium-borate buffer. The sample aliquots were titrated with $\mathrm{Fe}$ from 0 to $10 \mathrm{nM}$ (with a $0.5 \mathrm{nM}$ interval from 0 to $3 \mathrm{nM}$ and with a $2 \mathrm{nM}$ interval from 4 to $10 \mathrm{nM} \mathrm{Fe}$ ), and vials without $\mathrm{Fe}$ addition were prepared twice. Then, the competing ligand, SA, was added at a final concentration of $5 \mu \mathrm{M}$. The mixture was left to equilibrate for at least $8 \mathrm{~h}$ or typically overnight (Abualhaija and van den Berg, 2014). Before analysis, the Teflon vials for titration were preconditioned at least three times with seawater containing SA and the intended $\mathrm{Fe}$ addition. For each titration point, duplicate scans were done in the same Teflon vial as a voltammetric cell.

\subsection{Calculation of Fe speciation}

Ligand parameters, $\left[L_{\mathrm{t}}\right]$ and $K_{\mathrm{Fe}}^{\text {cond }}$, were obtained by fitting the data from the CLE-AdCSV titration into a nonlinear Langmuir model. One- and two-ligand models were applied, assuming one-ligand and two-ligand groups existed, respectively. The R software package was used for data fitting (Gerringa et al., 2014). The $\left[L_{t}\right]$ is reported in nanomoles equivalent of iron (nM eq. Fe) and the conditional stability constant values are reported as $\log K_{\mathrm{Fe}}^{\text {cond }}$.

The values of [ $\left.L_{\mathrm{t}}\right], \log K_{\mathrm{Fe} \text { 'c } \mathrm{C} \text { and }}^{\mathrm{ce}}$ De were used to calculate the concentration of natural unbound ligands, the excess ligand concentration $\left[L^{\prime}\right]$ and the side reaction coefficient of ligands $\left(\alpha_{\mathrm{Fe}}{ }^{\prime} \mathrm{L}\right.$; the product of $\left[L^{\prime}\right]$ and $K_{\mathrm{Fe} ' \mathrm{~L}}^{\text {cond }}$; Gledhill and Gerringa, 2017). The prime symbol (') in excess ligand concentrations denotes the free ligands not bound to Fe, whereas the prime symbol after $\mathrm{Fe}$ denotes the inorganic fraction of
Fe. The value of $\alpha_{\mathrm{Fe}}{ }^{\prime} \mathrm{L}$ is presented as a logarithmic value $\left(\log \alpha_{\mathrm{Fe}} \mathrm{L}\right)$ and is referred to as complexation capacity.

The value of the inorganic Fe side reaction coefficient $\left(\alpha_{\mathrm{Fe}}{ }^{\prime}\right)$ was determined using the hydrolysis constants of Liu and Millero (1999) at $S=36$ and at the $\mathrm{pH}$ of the analysis $(\mathrm{pH}=8.2)$. Hence, the value of $\log \alpha_{\mathrm{Fe}-\text { inorganic }}=10.4$ was used in the calculation for $\mathrm{Fe}$ speciation. The conditional stability constant of SA $\left(\log K_{\mathrm{Fe}}^{\text {cond }}(\mathrm{SA})=5.94\right)$ used in this study is based on the calibration of SA against diethylenetriaminepentaacetic acid by Gerringa et al. (2021).

\section{Results}

\subsection{Hydrography}

Water masses were identified by plotting the conservative temperature $(\Theta)$ versus the absolute salinity $\left(S_{\mathrm{A}}\right)$ (Tomczak and Godfrey, 2003) as generated by the freeware ODV (Schlitzer, 2018) from CTD data (Fig. 2a). The water mass description follows the definitions of Klinck et al. (2004) and Smith et al. (1999). A detailed description of hydrographic features of the WAP was described elsewhere (Moffat and Meredith, 2018; Klinck et al., 2004; Smith et al., 1999) and is briefly summarized here.

Two distinct horizontal currents exist in the study area: the coastal current (CC) and the Antarctic Circumpolar Current (ACC) (Fig. 1). In the vicinity of the WAP, the ACC is a large, strong, eastward-flowing current bordering the outer continental shelf. The CC is a strong but narrow southwesterly 

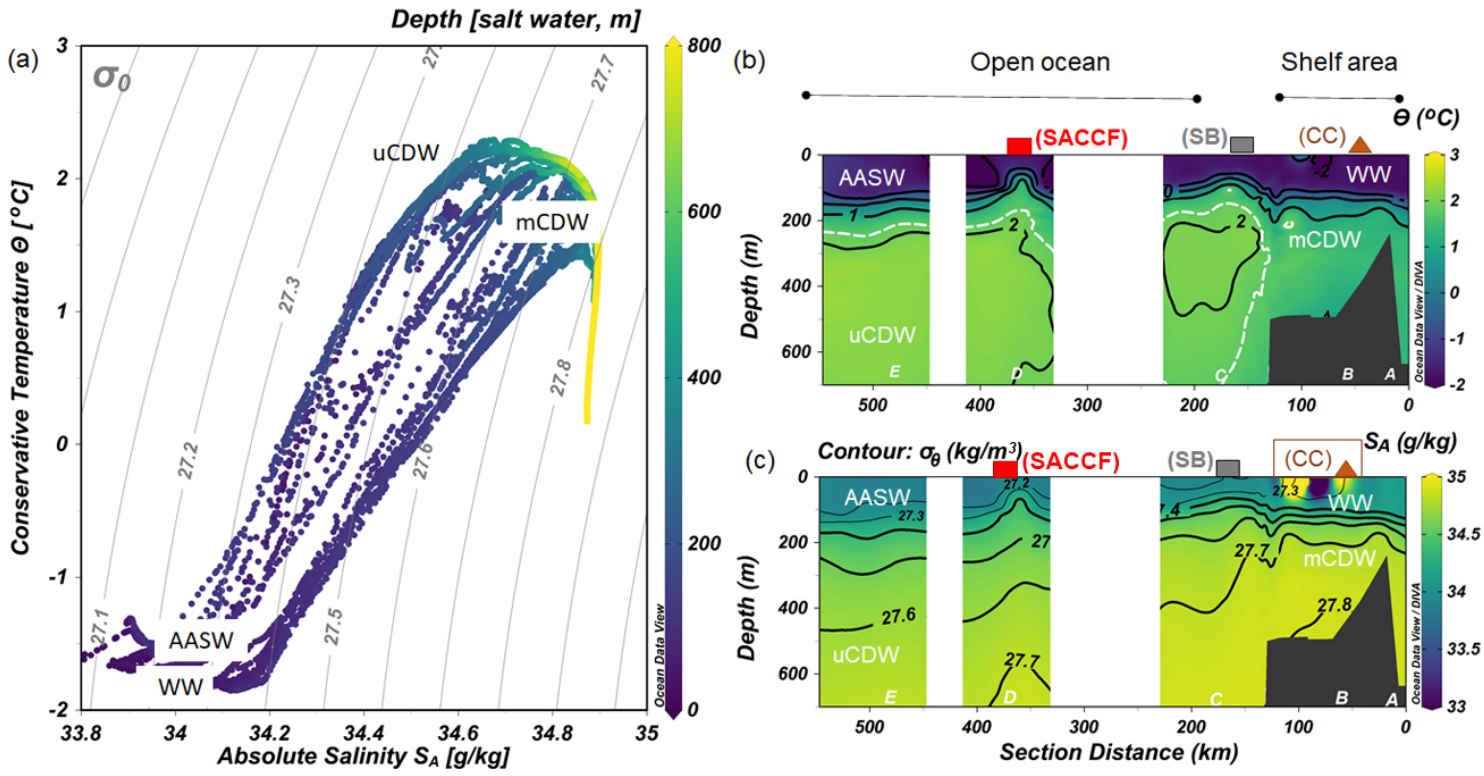

Figure 2. (a) Diagram of absolute salinity $\left(S_{\mathrm{A}}\right)$ versus conservative temperature $(\Theta)$ with isopycnal lines and colors denoting depth in meters. The distribution along the transect shown in Fig. 1 of (b) $\Theta$ and (c) $S_{\mathrm{A}}$ with density $\left(\sigma_{\theta}\right)$ as contours. The approximate boundary between $\mathrm{uCDW}$ and $\mathrm{mCDW}$ is marked with a dashed white line in (b). The values of $\Theta$ and $S_{\mathrm{A}}$ were generated by ODV software from CTD data.

flowing current that is forced by freshwater discharge and wind over the shelf (Grotov et al., 1998; Moffat and Meredith, 2018). The CC flows along the coast of the WAP from Bransfield Strait to Marguerite Bay (Fig. 1). Our sampling stations are located along a transect that is perpendicular to the prevailing currents. A number of oceanographic fronts exist along the ACC (Orsi et al., 1995). Two fronts intersect our sampling transect, namely the southern ACC front (SACCF) and the southern boundary (SB) of the ACC. These two fronts are present oceanward from the shelf (Fig. 1), usually about $50-200 \mathrm{~km}$ apart. Although their positions vary, these fronts remain approximately parallel to the continental shelf break along the WAP (Moffat and Meredith, 2018).

During the austral spring sampling period, winter water (WW; $\Theta<-1.8^{\circ} \mathrm{C}$ and $S_{\mathrm{A}} \sim 34.1$ ) still existed in the upper $100 \mathrm{~m}$ at stations in the shelf sea (Fig. 2b and c). In spring, Antarctic Surface Water (AASW) forms that has a higher temperature $\left(-1.5-1^{\circ} \mathrm{C}\right)$ and a lower salinity $\left(33.0<S_{\mathrm{A}}<33.7\right)$ than WW (Tomczak and Godfrey, 2003; Orsi et al., 1995). During sampling, AASW was present at stations outside the shelf region (stations D, E and C; Fig. 2b and c). The position of the SB marks the southern terminus of water with CDW properties. From the shelf break toward the open ocean, upper Circumpolar Deep Water (uCDW) existed at $300 \mathrm{~m}$ depth, characterized by $\Theta_{\max }=2{ }^{\circ} \mathrm{C}$ and a maximum of $S_{\mathrm{A}} \sim 34.7$. Near the WAP, the Antarctic Slope Front is missing (Klinck et al., 2004; Moffat and Meredith, 2018); hence, there is no barrier in the outer shelf region (Klinck et al., 2004). As a consequence, the shelf region is directly affected by the presence of the SB, resulting in subsurface intrusion of uCDW onto the continental shelf. This water mass is modified into cooler and less saline water, referred to as modified CDW (mCDW) (Hofmann and Klinck, 1998), and was present at stations A and B below $200 \mathrm{~m}$. Ocean eddies, modulated by wind forcing and interaction with the slope, are responsible for the transport of uCDW from the ACC into the inner shelf region. Intrusion of uCDW displaces shelf water, allowing a heat flux to the shelf area that triggers the melting of floating ice shelves. The melting of the glacial ice produces buoyant northward (offshore) flowing surface water that maintains the continuation of offshore-onshore water mass exchange (Klinck et al., 2004; Moffat and Meredith, 2018), although it did not seem to occur along our transect.

The ice coverage diminished with increasing distance from the shore, with stations nearshore (stations A and B) having sea-ice concentrations of $100 \%$ that fall to $60 \%$ at the shelf break (Station C). The ice cover dropped to $20 \%$ at Station D offshore, whereas Station E was ice-free.

\subsection{Fe speciation}

Stations located in the continental shelf (stations A and B) generally had higher $\left[L_{\mathrm{t}}\right]$ and $\mathrm{DFe}$ than stations sampled offshore (stations C, D and E; Fig. 3a and b). At the shelf stations, $\left[L_{\mathrm{t}}\right]$ varied from 1.23 to $6.43 \mathrm{nM} \mathrm{eq}$. Fe, and high $\left[L_{\mathrm{t}}\right](>2 \mathrm{nM})$ was present below $200 \mathrm{~m}$ in mCDW (Fig. 3a). In particular, at Station A nearest to the shore, $\left[L_{\mathrm{t}}\right]$ was higher than $2.5 \mathrm{nM}$ eq. Fe at the surface and reached up to $6.43 \mathrm{nM}$ eq. Fe at $400 \mathrm{~m}$ close to the sediment.

Concentrations of DFe were $<0.6 \mathrm{nM}(0.29-0.52 \mathrm{nM})$ in the upper $100 \mathrm{~m}$ but $>1 \mathrm{nM}(1.11$ to $2.26 \mathrm{nM})$ at depths below $200 \mathrm{~m}$ near the sediment (Fig. 3b). 
(a)

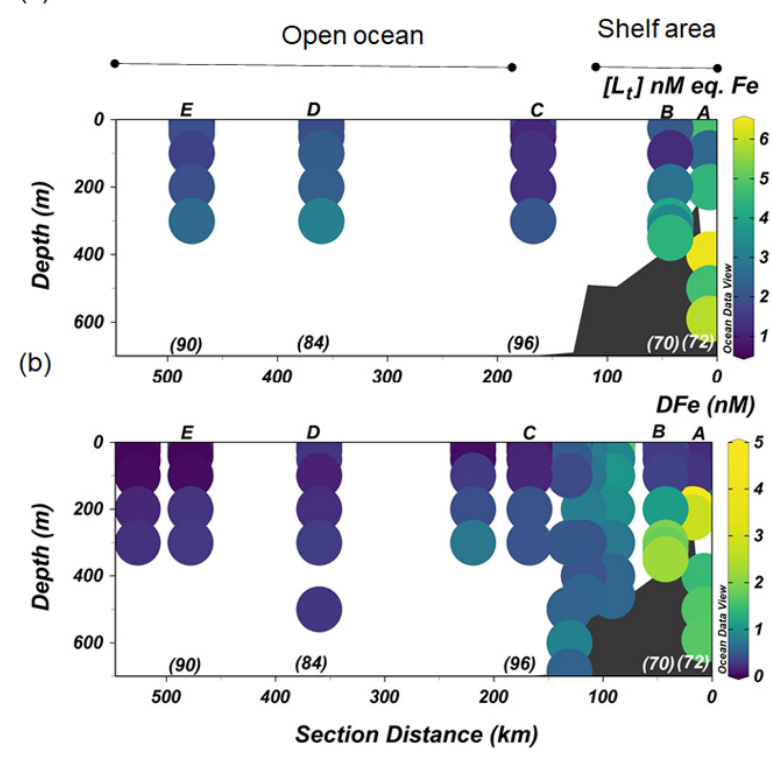

(c) $\quad\left[L_{t}\right] \mathrm{nM}$ eq. $\mathrm{Fe}$

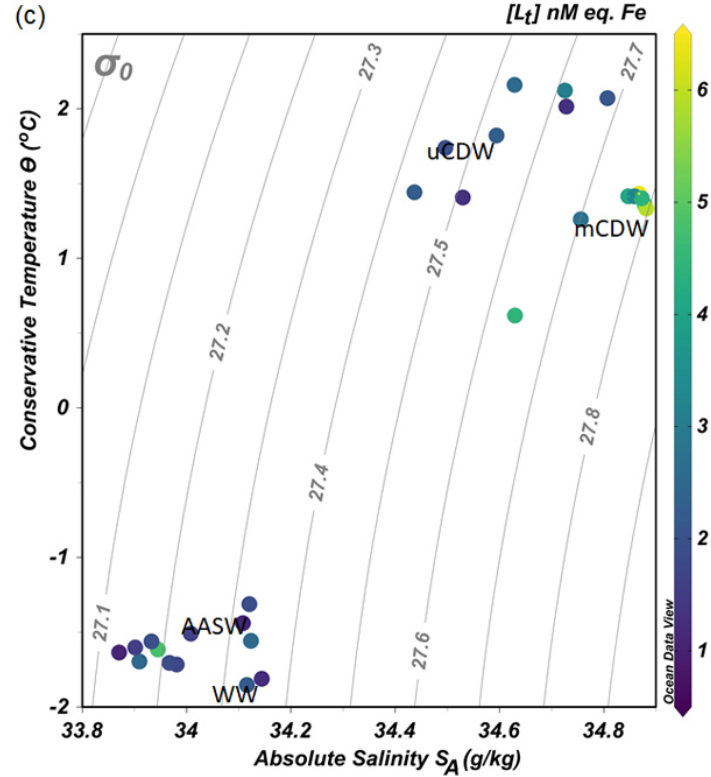

Figure 3. The distribution along the transect shown in Fig. 1 of (a) the concentrations of total Fe-binding ligands $\left[L_{\mathrm{t}}\right]$ and (b) concentrations of dissolved Fe (DFe; data from Seyitmuhammedov et al. (2021). (c) A diagram of $\Theta$ and $S_{\mathrm{A}}$ with colors denoting the values of [ $\left.L_{\mathrm{t}}\right]$. The letters above and numbers below the profiles in (a) and (b) indicate the stations. DFe data are presented using a nonlinear scale for clarity.

Further offshore towards the open ocean (stations C, D and E), $\left[L_{\mathrm{t}}\right]$ varied from 1.07 to $3.09 \mathrm{nM}$ eq. Fe (Fig. 3a), whereas DFe concentrations ranged from $<0.05$ to $0.47 \mathrm{nM}$ (Fig. 3b). At the shelf break, approximately where the SB was located, $\left[L_{\mathrm{t}}\right]$ was relatively low (Station C; Fig. 3a). Low DFe was observed in the upper $200 \mathrm{~m}$ offshore, reaching the lowest concentration $(<0.05 \mathrm{nM})$ at Station $\mathrm{E}$ farthest from the shelf (Fig. 3b).

Two ligand groups were distinguished only in two samples in open ocean waters, both collected at Station E (at 40 and $300 \mathrm{~m}$ ). The measured conditional stability constants for the stronger $L_{1}^{\prime}$ ligands and the progressively weaker $L_{2}^{\prime}$ ligands were distinct, and the values did not overlap. At $40 \mathrm{~m}, \log K_{1}=12.4 \pm 1.1$ and $\log K_{2}=10 \pm 1.1$, whereas at $300 \mathrm{~m}, \log K_{1}=11.3 \pm 0.6$ and $\log K_{2}=10.4 \pm 0.7$. However, the uncertainty for the ligand concentrations was relatively large for the two-ligand model: $L_{1}^{\prime}(0.66 \pm 1.81$ and $1.58 \pm 4.29 \mathrm{nM}$ eq. Fe at 40 and $300 \mathrm{~m}$, respectively) and $L_{2}^{\prime}$ $(1.10 \pm 4.32$ and $1.34 \pm 3.74 \mathrm{nM}$ eq. Fe at 40 and $300 \mathrm{~m}$, respectively), which implies that the one-ligand model fits the data better. Therefore, results of data fitting with the twoligand model will not be presented.

The values of $\log K_{\mathrm{Fe}}^{\text {cond }}$ varied within 1 order of magnitude between 11.1 and 12.3 (Fig. 4a). The lower log $K_{\mathrm{Fe} \text { ' } \mathrm{c}}^{\mathrm{con}}$ in AASW coincided with the lowest $\log \alpha_{\mathrm{Fe}} \mathrm{L}$ (AASW: mean $\log \alpha_{\mathrm{Fe}}{ }^{\mathrm{L}}=2.6 \pm 0.3, N=13$; Fig. $4 \mathrm{~b}$ ). The largest $\log K_{\mathrm{Fe}}^{\text {cond }}$ and $\log \alpha_{\mathrm{Fe}} \mathrm{L}$ were measured in shelf waters, particularly in mCDW (mean $\log \alpha_{\mathrm{Fe}^{\prime} \mathrm{L}}=3.4 \pm 0.2, N=8$; Fig. 4b). Overall, a decreasing trend of $\log K_{\mathrm{Fe}}^{\mathrm{con} L}$ and $\log \alpha_{\mathrm{Fe}}$ was observed in mCDW, uCDW and AASW with the highest values in mCDW and lowest in AASW.

Ligands were always present in excesses of DFe, with $\left[L^{\prime}\right]$ ranging from 0.75 to $4.98 \mathrm{nM}$ eq. Fe. High excess ligand concentrations ( $>2 \mathrm{nM}$ eq. Fe) were observed close to shore (Station A), declining towards the shelf break and reaching the lowest $\left[L^{\prime}\right]$ at Station $C$ near the shelf break (Fig. 5a). Further offshore (stations D and E), $\left[L^{\prime}\right]$ remains fairly constant at $1-2 \mathrm{nM}$ eq. of Fe.

\section{Discussion}

The ligand concentrations measured during our study (1.07$6.43 \mathrm{nM}$ eq. Fe; Fig. 3a) are consistent with the broad range of Fe-binding ligand concentrations measured in DFe speciation studies in the Southern Ocean (Boye et al., 2001; Lin and Twining, 2012; Nolting et al., 1998; Thuróczy et al., 2011). Previously reported $\left[L_{\mathrm{t}}\right]$ in the Southern Ocean varies from 0.5 to $1.84 \mathrm{nM}$ eq. Fe in the Atlantic sector (Thuróczy et al., 2011), 2.2 to $12.3 \mathrm{nM}$ eq. Fe in the Pacific sector (Nolting et al., 1998) and 0.44 to $1.61 \mathrm{nMeq}$. Fe in the Indian sector (Gerringa et al., 2008). The $\left[L_{t}\right]$ in Antarctic polynyas ranges between 0.3 and $1.6 \mathrm{nM}$ eq. Fe (Gerringa et al., 2019; Thuróczy et al., 2012), whereas in regions with sea-ice coverage, $\left[L_{\mathrm{t}}\right]$ in underlying water is relatively high, with values of $4.9-9.6 \mathrm{nM}$ eq. Fe and up to $72.1 \mathrm{nM}$ eq. Fe within the sea ice (Lannuzel et al., 2015; Genovese et al., 2018). 

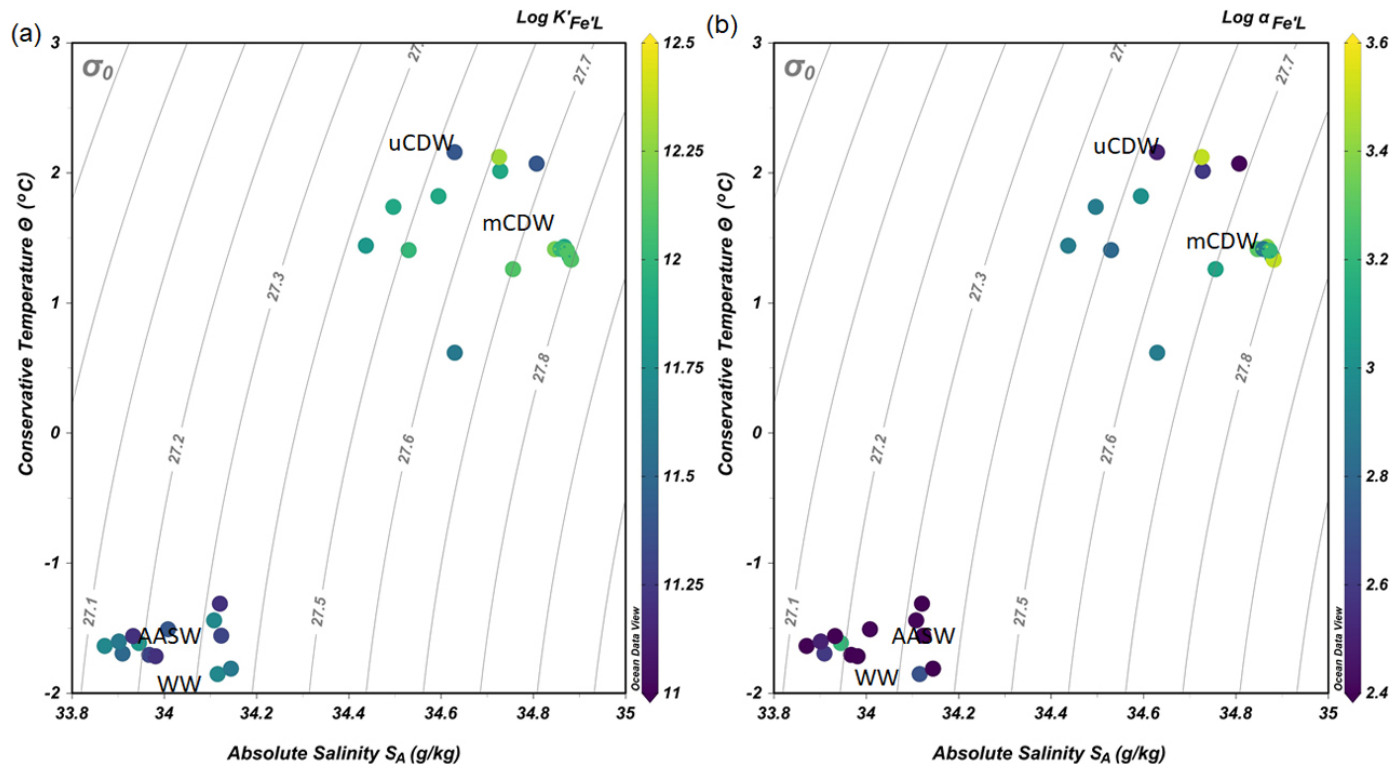

Figure 4. (a) The binding strength, $\log K_{\mathrm{Fe}}^{\mathrm{con} L}$, and (b) complexation capacity, $\log \alpha_{\mathrm{Fe}}{ }^{\prime} \mathrm{L}$, plotted in a diagram of $\Theta$ and $S_{\mathrm{A}}$. The color scale indicates the values of $\log K_{\mathrm{Fe}^{\prime} \mathrm{L}}^{\mathrm{cond}}$ and $\log \alpha_{\mathrm{Fe}}{ }^{\prime} \mathrm{L}$.

\subsection{Fe-binding ligands along the transect from the shelf to the open ocean}

The high sea-ice cover on the continental shelf obstructs the light penetration into the water column, inhibiting the development of an early spring bloom. Therefore, bloomgenerated ligands are less likely to be found. However, microbial excretion from sea-ice algae and bacteria within and just beneath the sea ice release EPSs which can form Febinding ligands (Lannuzel et al., 2015; Norman et al., 2015; Genovese et al., 2018; Hassler et al., 2017). The planktonic community in spring is dominated by diatoms and haptophytes (Phaeocystis antarctica) (Joy-Warren et al., 2019; Arrigo et al., 2017). According to Lannuzel et al. (2015), the omnipresence of tube-dwelling diatoms (Berkelaya sp.) attached via EPSs to the bottom of the sea ice was responsible for relatively high $\left[L_{\mathrm{t}}\right]$ in under-ice seawater, indicating that EPSs could elevate seawater $\left[L_{\mathrm{t}}\right]$ in areas of sea-ice cover. In addition, a laboratory study has shown that cultured $P$. antarctica appears to excrete EPSs in relatively high concentrations (Norman et al., 2015) with similar binding strength $\left(\log K_{\mathrm{Fe} L}^{\mathrm{cond}} 11.5-12\right)$ to those measured in this study $(\log$ $\left.K_{\mathrm{Fe} \text { ' }}^{\text {cond }} 11.1-12.3\right)$. At the ice-covered shelf stations, the high $\left[L_{\mathrm{t}}\right]$ in the upper water column implies that ice-algal exudates are a source of Fe-binding ligands (stations A and B; Fig. 3a). Further from the coast, EPSs from phytoplankton likely provide an additional surface source of ligands.

High $\left[L_{\mathrm{t}}\right](>2.75 \mathrm{nM}$ eq. Fe $)$ was observed in mCDW (Fig. 3c) with a narrow range of $\log K_{\mathrm{Fe}}^{\text {cond }}(11.1-11.9$; Fig. 4a), which suggests similar chemical characteristics and a common origin. Given that $\mathrm{uCDW}$ at the shelf break has
$\left[L_{\mathrm{t}}\right]$ lower than $2.5 \mathrm{nM}$ eq. Fe and relatively low DFe concentrations, the high $\left[L_{\mathrm{t}}\right]$ in mCDW appears to be supplied by the shelf sediments. Upwelling and contact with the sediment of uCDW presumably results in the resuspension of organic matter and pore water from the sediment supplying ligands and DFe to the water column. Indeed, ligand input in the proximity of sediments was previously observed in upwelling regions over the continental shelf and in coastal areas (Gerringa et al., 2008; Buck et al., 2017). Subsequent upwelling processes may transport the ligands to the upper water column, including rDOM. Moreover, the intrusion of uCDW also provides heat (Smith et al., 1999), which may cause glacial and sea-ice melt. The melting of sea ice (i.e., first year pack ice) supplies ligands to surrounding seawater (Genovese et al., 2018), whereas glacial ice is not expected to contribute organic ligands. The estimated flux of $\left[L_{\mathrm{t}}\right]$ from melting pack ice in spring can reach up to micromolar levels per square meter of pack ice per day (Genovese et al., 2018), showing the significance of the sea-ice melt contribution to the ligand pool. Overall, the high $\left[L_{\mathrm{t}}\right]$ in the shelf region (Fig. 3a) can be explained by several ligand sources associated with sea ice, including the melting of sea ice, as well as sediment resuspension and upwelling.

At the continental shelf break (Station $\mathrm{C}$ ) in the vicinity of the SB, the lowest $\left[L_{t}\right]$ was found in the upper $200 \mathrm{~m}$ of the water column. The presence of the SB is noticeable by the increased upward tilt of the isopycnals (Fig. 2a) (Orsi et al., 1995; Klinck et al., 2004). Here the ACC interacts with the continental slope (Orsi et al., 1995), propagating ocean eddies that subsequently cause cross-shelf water intrusion (Moffat and Meredith, 2018). The subsurface intrusion of 


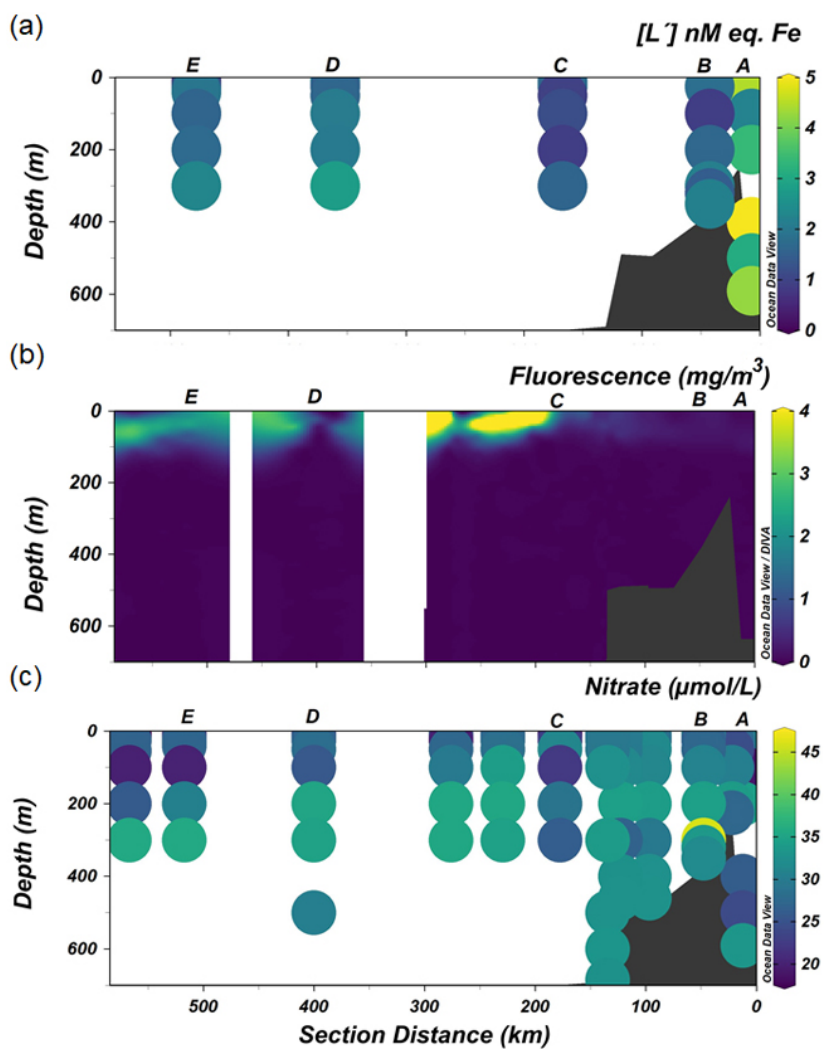

Figure 5. The distribution along the transect shown in Fig. 1 of (a) excess ligand concentrations $\left[L^{\prime}\right]$, (b) fluorescence and (c) nitrate.

$\mathrm{uCDW}$ and its associated turbulence may cause vertical water mass mixing at the proximate location of the SB. The little ice cover at the shelf break compared to the inner shelf allows more light penetration, triggering a bloom, as indicated by a fluorescence maximum observed at Station C (Fig. 5b). The bloom and its related microbial activities could release Fe-binding ligands. However, given the consistently low and constant distribution of $\left[L_{\mathrm{t}}\right]$ at the shelf break, it seems that mixing determines the distribution and net concentrations of ligands (Fig. 3a) and likely the microbial species composition as well. Different microbial species have different rates of organic ligand production, and different microbial species may produce different types of organic ligands (Norman et al., 2015). The influence of mixing on ligands and microbial species composition is confirmed by the relatively constant distribution of DFe and macronutrients (i.e., nitrate; Fig. 5c) at the same station, indicating that prominent mixing at the shelf break indeed is a major factor.

Further oceanward from the shelf break, $\left[L_{\mathrm{t}}\right]$ was $>1 \mathrm{nM}$ eq. of Fe (stations $\mathrm{D}$ and E; Fig. 3a), probably related to the spring bloom at this location. Satellite-based data (Arrigo et al., 2017), showed that open water formed 1 month earlier offshore than nearshore (station A and B), implying that the melting of sea ice offshore (stations D and E) oc- curred before and during our occupation. The melting of sea ice released nutrients and micronutrients such as Fe (Lannuzel et al., 2016; Sherrell et al., 2018), which together with the availability of light stimulated the spring bloom. Such a bloom in turn is a source of Fe-binding ligands in the upper water column (Gledhill and Buck, 2012; Boye et al., 2001; Croot et al., 2004; Gerringa et al., 2019). Arrigo et al. (2017) reported that a bloom in its early stages was observed underneath variable sea-ice cover seaward from the shelf break. Indeed, the fluorescence maxima observed in the upper $100 \mathrm{~m}$ at the offshore stations (stations D and E; Fig. 5b) concurred with the depletion of DFe and drawdown of macronutrients ( $\mathrm{N}$ and $\mathrm{Si}$ ), illustrating the presence of a bloom. Siderophores are expected to be produced upon Fe depletion by marine microbes as a strategy to acquire Fe (Butler, 2005; Buck et al., 2010; Mawji et al., 2008; Velasquez et al., 2011). Similarly, as detailed above for the shelf stations, the exudation of EPSs from diatoms and haptophytes could be an important addition to the organic ligand pool. Moreover, polysaccharide ligands will be released by microbial cells during the bloom, as well as via grazing (Sato et al., 2007; Laglera et al., 2019b) and viral lysis (Poorvin et al., 2011; Slagter et al., 2016). Additionally, the ratios of labile particulate $\mathrm{Fe}$ to labile particulate $\mathrm{Mn}(0.27 \pm 0.49 \mathrm{nM}$; Seyitmuhammedov et al. (in review)) indicate that $\mathrm{Fe}$ has a biogenic origin in the offshore waters (Twining et al., 2004). Therefore, we suggest that the origin of $\left[L_{t}\right]$ offshore was, next to the melting of sea ice, the result of in situ production of organic ligands during the bloom and passive generation from microbial processes associated with the bloom.

The lowest concentrations of DFe $(<0.05 \mathrm{nM})$ were observed at stations $\mathrm{D}$ and $\mathrm{E}$ and were a result of both biological uptake and limited supply. This area most likely represents $\mathrm{Fe}$-limited conditions as indicated by declining $\mathrm{Si}^{*}\left(\mathrm{Si}^{*}=[\mathrm{Si}]-[\mathrm{N}]\right)$ values and high ratios of [nitrate] / DFe (Fig. 6a and b). The value of $\mathrm{Si}^{*}$ serves as a proxy for $\mathrm{Fe}$ limitation where $\mathrm{Fe}$ stress leads to the preferential drawdown of $\mathrm{Si}$ compared to $\mathrm{N}$ by diatoms in surface water (Takeda, 1998). A negative $\mathrm{Si}^{*}$ indicates Fe-limiting conditions, assuming that $\mathrm{Si}$ and $\mathrm{N}$ are required in a $1: 1$ ratio by diatoms (Brzezinski et al., 2002). In our dataset, although there were no negative values for $\mathrm{Si}^{*}$, some $\mathrm{Si}^{*}$ values at the open ocean stations were close to zero. Our data indicate that although there is no Fe limitation during our sampling period, Fe limitation could potentially develop later in the season. Typically, organic ligands excreted under Fe-limited conditions have a strong affinity for Fe (Maldonado et al., 2005; Mawji et al., 2008), i.e., a high $\log K_{\mathrm{Fe} \text { 'L }}^{\text {cond }}(>12)$. However, a relatively low $\log K_{\mathrm{Fe} \text { ' } \mathrm{L}}^{\text {cond }}$ is observed in AASW relative to deeper uCDW and mCDW (Fig. 4a). This indicates that in offshore AASW where Fe limitation is expected, the contribution of siderophores is modest. Indeed, recent studies showed that only $<10 \%$ of Fe is complexed by siderophores (Boiteau et al., 2019; Bundy et al., 2018), suggesting that the binding strength of the overall ligand pool is not always a good 


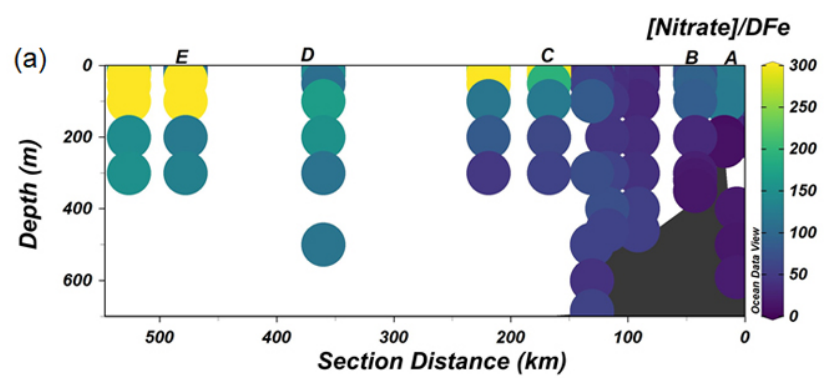

(b)

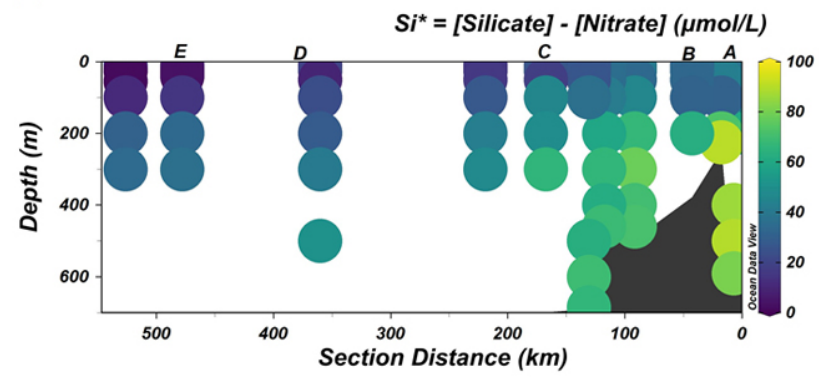

Figure 6. The distribution of $\mathrm{Si}^{*}$ (a) and the ratio of [Nitrate] / DFe (b) along the transect shown in Fig. 1.

indicator of the presence of a particular ligand group if multiple ligand sources are present. Moreover, in the presence of light, organic ligands can undergo photodegradation (Hassler et al., 2020), and thus the chemical structure can be altered into a slightly weaker ligand type (Barbeau et al., 2001; Powell and Wilson-Finelli, 2003). Mopper et al. (2015) suggested that the absorption of solar radiation by chromophoric dissolved organic matter as part of the ligand pool. These chromophoric compounds are commonly produced by seaice algae (Norman et al., 2011), leading to the photochemical transformation of these compounds. These photo-oxidative processes can thus also explain the shift in $\log K_{\mathrm{Fe} ' \mathrm{~L}}^{\text {cond }}$ in the AASW to lower values compared to deeper uCDW and mCDW.

The presence of the southern ACC front (SACCF) and SB fronts affects bloom conditions. As shown by Arrigo et al. (2017), high chlorophyll $a$ concentrations were observed in surface waters in between the SB and SACCF, which suggests that the distribution of phytoplankton biomass is affected by physical processes in the area. The SB also appears to mark the boundary between offshore organic ligands that result from a combination of the earlier sea-ice melt and in situ production and/or generation associated with offshore blooms and organic ligands on the shelf that result from a combination of ice-algal exudation, sea-ice melt and sediment resuspension. In the region near the SB at the shelf break, water mass mixing due to the baroclinically unstable water column seems to have caused consistent distributions of $\left[L_{t}\right]$ (Fig. 3a). Further offshore, ligands are most likely associated with the bloom, but the distribution of ligands is also affected by enhanced vertical mixing and intensified currents proximal to the area of the fronts. Solar radiation enhances stratification and drives the formation of the spring bloom, whereas deep mixing can both hinder as well as stimulate bloom formation based on the balance between the availability of light and nutrients (Arrigo et al., 2017). It thus seems likely that the balance between mixing and stratification results in variable $\left[L_{t}\right]$ in the area around the SACCF (stations D and E; Fig. 3a).

\subsection{Implications for primary productivity}

In general, we found $\left[L^{\prime}\right]>0.75 \mathrm{nM}$ eq. Fe (Fig. 5a), which accounts for approximately $80 \%$ of $\left[L_{t}\right]$. This implies that at least $80 \%$ of total ligands measured are available to bind $\mathrm{Fe}$, although the total complexation capacity of ligands is also determined by its $\log K_{\mathrm{Fe}}^{\mathrm{con}}$. The highest complexation capacity $\log \alpha_{\mathrm{Fe}}$ 'L was found in mCDW on the shelf (Fig. $4 \mathrm{~b}$ ), and it concurred with the highest concentrations of DFe in mCDW (Figs. 3b and 4b). The high complexation capacity of ligands on the shelf increases the potential of organic ligands to stabilize additional $\mathrm{Fe}$ input to the shelf waters (Lannuzel et al., 2015; Gerringa et al., 2019; Thuróczy et al., 2012) and lengthen the residence time of DFe (Gerringa et al., 2015). A longer residence time has a positive feedback on the development of local primary productivity upon sea ice melting (Arrigo et al., 2017), supplying DFe to primary producers on the shelf, which were dominated by Phaeocystis antarctica during our sampling period (Joy-Warren et al., 2019). Moreover, the results of our oxygen isotope $\left({ }^{18} \mathrm{O} /{ }^{16} \mathrm{O}\right.$, conventionally reported into delta-notation as $\delta^{18} \mathrm{O}$; Seyitmuhammedov et al., 2021) analysis showed that $\delta^{18} \mathrm{O}$ values ranged from $-0.56 \%$ o to $0.06 \%$. These values were used to estimate fractions of sea-ice meltwater $(-1.9 \%-1.1 \%)$ and meteoric meltwater (precipitation and glacial; $0.3 \%-3.9 \%$ ). Based on those results, meltwater associated with runoff and glacial discharge is present in the upper $200 \mathrm{~m}$ of the shelf region and probably is a source of particulate and dissolved Fe that will increase under continued climate change. However, whether $\mathrm{Fe}$ in particulate form will partition into the dissolved pool via the ligand-driven dissolution of $\mathrm{Fe}$ also depends on the fraction of labile particulate Fe. In addition, local primary productivity not only relies on the DFe input from, for example, meltwater and glacial debris (Klunder et al., 2011; Lannuzel et al., 2016) but probably also on the input of Co and Mn (Saito et al., 2010; Wu et al., 2019; Middag et al., 2013) as these elements showed co-limitation in the Southern Ocean (Middag et al., 2013; Saito and Goepfert, 2008).

Besides affecting the shelf conditions, ice melt also produces buoyant northward-flowing surface water which may facilitate DFe transport from the shelf to the open ocean, supplying DFe for primary production offshore, but this effect was not noticeable in the transport data for this specific transect. However, the conditions along the WAP were not homogenous, and elevated $\mathrm{Fe}$ (up to $4.88 \mathrm{nM}$ for DFe; 
Seyitmuhammedov et al. (2021) concentrations northeast of our transect were observed in the upper $100 \mathrm{~m}$, suggesting that some of the observed ligands might have been transported southwesterly with the CC. This high DFe stabilized by organic ligands will probably be transported further to the southwest where a coastal polynya is commonly observed in Marguerite Bay (Arrigo et al., 2015). Such transport would supply DFe to the highly productive Marguerite Bay polynya and fuel phytoplankton blooms in these ice-free waters but could also be partly transported offshore in the region southwest of our transect. However, the relative amount of DFe bound to organic ligands can vary, and it is also strongly influenced by the continued change in environmental conditions due to global warming (Slagter et al., 2017; Ye et al., 2020), making it likely such a transport of DFe to the southwest or offshore will change as well.

Global warming has caused glaciers to retreat and induced significant loss of sea ice, particularly in the Antarctic Peninsula area (Henley et al., 2019; Stammerjohn et al., 2012; Turner et al., 2020). The sea-ice extent over the southern Bellingshausen Sea has decreased in recent decades, creating open water and lengthening the ice-free season (Turner et al., 2013). This results in increased solar irradiance and enhanced stratification (Henley et al., 2019), which can lead to an alteration of the phytoplankton community structure. As previously reported, variable light conditions favor the growth of Phaeocystis antarctica over diatoms (Joy-Warren et al., 2019; Alderkamp et al., 2012). In contrast, smaller-cell diatoms are better adapted to increased sea surface temperature (Schofield et al., 2017). Changes in planktonic community composition affect net primary production and overall carbon drawdown, which lead to further alteration of the food web and carbon cycling (Schofield et al., 2017; JoyWarren et al., 2019; Arrigo et al., 1999; Alderkamp et al., 2012). These and other ongoing changes in the food web will also affect the production of dissolved organic carbon (DOC) and thus ligands as they form a fraction of the DOC pool (Gledhill and Buck, 2012; Whitby et al., 2020). Generally, one expects that increased DOC production would lead to more ligands, but the binding strength depends on which molecules are formed (Gledhill and Buck, 2012; Hassler et al., 2017). Additionally, intensified light exposure alters log $K_{\mathrm{Fe} \text { 'L }}^{\text {cond }}$ by photo-oxidative processes, possibly reducing the complexation capacity and binding strength for $\mathrm{Fe}$ (Barbeau et al., 2001; Powell and Wilson-Finelli, 2003; Mopper et al., 2015), as well as the bioavailability (Hassler et al., 2020). Furthermore, complexation capacity is affected by $\mathrm{pH}$, implying that ongoing ocean acidification also influences the speciation of $\mathrm{Fe}$ (Ye et al., 2020), although the extent to which these changes are important is not yet known. The melting of sea ice with entrapped sediment potentially releases organic ligands (Genovese et al., 2018). Additionally, organic ligands from microbial excretions are expected to be abundant at the base of sea ice (Norman et al., 2015). Overall, the continued sea-ice melt and glacial retreat can be ex- pected to increase the supply of $\mathrm{Fe}$ (Lannuzel et al., 2016), other micronutrients ( $\mathrm{Co}, \mathrm{Mn}$, etc.) and Fe-binding ligands (Lin and Twining, 2012), but the consequences for their complexation capacity and overall bioavailability of $\mathrm{Fe}$ remain elusive. If DFe becomes progressively more available in the Southern Ocean, phytoplankton growth could increase until another process becomes limiting, such as the availability of another micronutrient or macronutrient. Many uncertainties remain, but the changing environmental conditions of the WAP due to climate change will affect marine biogeochemical cycles and influence productivity beyond the Southern Ocean as the Southern Ocean is an important hub in ocean circulation and its waters eventually supply nutrients to other regions (e.g., Middag et al., 2020).

\section{Summary}

Our results indicate that organic Fe-binding ligands in surface water on the continental shelf of the WAP are associated with ice-algal exudates and the addition of ligands from melting sea ice. In the water column close to the continental slope and shelf sediments, the resuspension of sediment followed by upwelling processes appears to be another source of ligands. From the continental shelf-break oceanward, sources of Fe-binding ligands are likely related to offshore phytoplankton blooms either actively produced during the bloom or passively generated by microbial processes associated with the bloom. The distribution of ligands is affected by the two major fronts in the region, the SACCF and SB. The SB along the shelf break not only marks the boundary between the shelf and open ocean but also marks the border between organic ligands associated with the bloom offshore and organic ligands on the shelf originating from sea ice and sedimentrelated sources, such as ice-algal exudation, sea-ice melt and sediment resuspension. Overall, excess ligands comprised up to $80 \%$ of the total ligand concentrations, implying the potential to solubilize additional $\mathrm{Fe}$ input. The ligands in denser $\mathrm{mCDW}$ on the shelf have a higher complexation capacity for $\mathrm{Fe}$ and are thus capable of increasing the residence time of $\mathrm{Fe}$ as $\mathrm{DFe}$, which fuels local primary production later in the season upon ice melt.

Data availability. Data can be found at https://dataverse.nioz.nl/ dataset.xhtml?persistentId=doi:10.25850/nioz/7b.b.5 (Ardiningsih, 2021, last access: 20 January 2021.

Author contributions. IA and KS performed the analysis. IA and LJAG prepared the content of the manuscript. RM collected the samples, lead the design of this research and edited the manuscript. SGS and CHS contributed to research design and edited the manuscript. KRA performed the research and edited the manuscript. GJR edited the manuscript. All authors contributed to the final version of the manuscript. 
Competing interests. The authors declare that they have no conflict of interest.

Acknowledgements. The authors would like to thank the captain and his crew of the R/V Nathaniel B. Palmer, as well as AnneCarlijn Alderkamp and all other participants, for their efforts and support. Our colleagues in the nutrient lab at NIOZ are acknowledged for analyzing nutrients. The IAEA is grateful to the government of the Principality of Monaco for the support provided to its environment laboratories.

Financial support. This research has been supported by the Koninklijk Nederlands Instituut voor Onderzoek der Zee (OCS). Indah Ardiningsih was financed by the Indonesia Endowment Fund for Education (LPDP), and Kyyas Seyitmuhammedov received a scholarship from the University of Otago. Kevin R. Arrigo was funded by a grant from the National Science Foundation Office of Polar Programs (ANT-1063592).

Review statement. This paper was edited by Koji Suzuki and reviewed by Anh Pham and three anonymous referees.

\section{References}

Abualhaija, M. M. and van den Berg, C. M. G.: Chemical speciation of iron in seawater using catalytic cathodic stripping voltammetry with ligand competition against salicylaldoxime, Mar. Chem., 164, 60-74, https://doi.org/10.1016/j.marchem.2014.06.005, 2014.

Alderkamp, A.-C., Kulk, G., Buma, A. G. J., Visser, R. J. W., Van Dijken, G. L., Mills, M. M., and Arrigo, K. R.: The effect of iron limitation on the photophysiology of phaeocystis antarctica (prymnesiophyceae) and fragilariopsis cylindrus (bacillariophyceae) under dynamic irradiance, J. Phycol., 48, 45-59, https://doi.org/10.1111/j.1529-8817.2011.01098.x, 2012.

Ardiningsih, I.: Fe-binding organic ligands in coastal and frontal regions of the western Antarctic Peninsula [data set], available at: https://dataverse.nioz.nl/dataset.xhtml?persistentId=doi: 10.25850/nioz/7b.b.5, last access: 20 January 2021.

Arrigo, K. R., Robinson, D. H., Worthen, D. L., Dunbar, R. B., DiTullio, G. R., VanWoert, M., and Lizotte, M. P.: Phytoplankton Community Structure and the Drawdown of Nutrients and $\mathrm{CO}_{2}$ in the Southern Ocean, Science, 283, 365-367, https://doi.org/10.1126/science.283.5400.365, 1999.

Arrigo, K. R., van Dijken, G., and Long, M.: Coastal Southern Ocean: A strong anthropogenic $\mathrm{CO}_{2}$ sink, Geophys. Res. Lett., 35, L21602, https://doi.org/10.1029/2008GL035624, 2008.

Arrigo, K. R., van Dijken, G. L., and Strong, A. L.: Environmental controls of marine productivity hot spots around Antarctica, J. Geophys. Res.-Oceans, 120, 5545-5565, https://doi.org/10.1002/2015JC010888, 2015.

Arrigo, K. R., van Dijken, G. L., Alderkamp, A.-C., Erickson, Z. K., Lewis, K. M., Lowry, K. E., Joy-Warren, H. L., Middag, R., Nash-Arrigo, J. E., Selz, V., and van de Poll, W.: Early Spring Phytoplankton Dynamics in the Western
Antarctic Peninsula, J. Geophys. Res.-Oceans, 122, 9350-9369, https://doi.org/10.1002/2017jc013281, 2017.

Barbeau, K., Rue, E. L., Bruland, K. W., and Butler, A.: Photochemical cycling of iron in the surface ocean mediated by microbial iron(iii)-binding ligands, Nature, 413, 409-413, https://doi.org/10.1038/35096545, 2001.

Biller, D. V. and Bruland, K. W.: Analysis of Mn, Fe, Co, $\mathrm{Ni}, \mathrm{Cu}, \mathrm{Zn}, \mathrm{Cd}$, and $\mathrm{Pb}$ in seawater using the Nobiaschelate PA1 resin and magnetic sector inductively coupled plasma mass spectrometry (ICP-MS), Mar. Chem., 130, 12-20, https://doi.org/10.1016/j.marchem.2011.12.001, 2012.

Boiteau, R. M., Fitzsimmons, J. N., Repeta, D. J., and Boyle, E. A.: Detection of iron ligands in seawater and marine cyanobacteria cultures by high-performance liquid chromatographyinductively coupled plasma-mass spectrometry, Anal. Chem., 85, 4357-4362, https://doi.org/10.1021/ac3034568, 2013.

Boiteau, R. M., Mende, D. R., Hawco, N. J., McIlvin, M. R., Fitzsimmons, J. N., Saito, M. A., Sedwick, P. N., DeLong, E. F., and Repeta, D. J.: Siderophore-based microbial adaptations to iron scarcity across the eastern Pacific Ocean, P. Natl. Acad. Sci. USA, 113, 14237-14242, https://doi.org/10.1073/pnas.1608594113, 2016.

Boiteau, R. M., Till, C. P., Coale, T. H., Fitzsimmons, J. N., Bruland, K. W., and Repeta, D. J.: Patterns of iron and siderophore distributions across the California Current System, Limnol. Oceanogr., 64, 376-389, https://doi.org/10.1002/lno.11046, 2019.

Boye, M., van den Berg, C. M. G., de Jong, J. T. M., Leach, H., Croot, P., and de Baar, H. J. W.: Organic complexation of iron in the Southern Ocean, Deep-Sea Res. Pt. I, 48, 1477-1497, https://doi.org/10.1016/s0967-0637(00)00099-6, 2001.

Brzezinski, M. A., Pride, C. J., Franck, V. M., Sigman, D. M., Sarmiento, J. L., Matsumoto, K., Gruber, N., Rau, G. H., and Coale, K. H.: A switch from $\mathrm{Si}(\mathrm{OH})_{4}$ to $\mathrm{NO}_{3}^{-}$depletion in the glacial Southern Ocean, Geophys. Res. Lett., 29, 5.1-5.4 https://doi.org/10.1029/2001g1014349, 2002.

Buck, K. N., Selph, K. E., and Barbeau, K. A.: Iron-binding ligand production and copper speciation in an incubation experiment of Antarctic Peninsula shelf waters from the Bransfield Strait, Southern Ocean, Mar. Chem., 122, 148-159, https://doi.org/10.1016/j.marchem.2010.06.002, 2010.

Buck, K. N., Sedwick, P. N., Sohst, B., and Carlson, C. A.: Organic complexation of iron in the eastern tropical South $\mathrm{Pa}$ cific: Results from US GEOTRACES Eastern Pacific Zonal Transect (GEOTRACES cruise GP16), Mar. Chem., 201, 229-251, https://doi.org/10.1016/j.marchem.2017.11.007, 2017.

Bundy, R. M., Boiteau, R. M., McLean, C., Turk-Kubo, K. A., McIlvin, M. R., Saito, M. A., Van Mooy, B. A. S., and Repeta, D. J.: Distinct Siderophores Contribute to Iron Cycling in the Mesopelagic at Station ALOHA, Frontiers in Marine Science, 5, 61, https://doi.org/10.3389/fmars.2018.00061, 2018.

Burkhardt, B. G., Watkins-Brandt, K. S., Defforey, D., Paytan, A., and White, A. E.: Remineralization of phytoplankton-derived organic matter by natural populations of heterotrophic bacteria, Mar. Chem., 163, 1-9, https://doi.org/10.1016/j.marchem.2014.03.007, 2014.

Butler, A.: Marine siderophores and microbial iron mobilization, Biometals, 18, 369-374, https://doi.org/10.1007/s10534005-3711-0 2005 
Croot, P. L., Andersson, K., Öztürk, M., and Turner, D. R.: The distribution and speciation of iron along $6^{\circ} \mathrm{E}$ in the Southern Ocean, Deep-Sea Res. Pt. II, 51, 2857-2879, https://doi.org/10.1016/j.dsr2.2003.10.012, 2004.

de Baar, H. J.: On iron limitation of the Southern Ocean: experimental observations in the Weddell and Scotia Seas, Mar. Ecol. Prog. Ser., 65, 105-122, https://doi.org/10.3354/meps065105, 1990.

de Baar, H. J., Boyd, P. W., Coale, K. H., Landry, M. R., Tsuda, A., Assmy, P., Bakker, D. C., Bozec, Y., Barber, R. T., and Brzezinski, M. A.: Synthesis of iron fertilization experiments: from the iron age in the age of enlightenment, J. Geophys. Res.-Oceans, 110, C09S16, https://doi.org/10.1029/2004JC002601, 2005.

De Jong, J. T. M., Stammerjohn, S. E., Ackley, S. F., Tison, J. L., Mattielli, N., and Schoemann, V.: Sources and fluxes of dissolved iron in the Bellingshausen Sea (West Antarctica): The importance of sea ice, icebergs and the continental margin, Mar. Chem., 177, 518-535, https://doi.org/10.1016/j.marchem.2015.08.004, 2015.

De La Rocha, C.: 8.4 - The Biological Pump, in: The oceans and marine geochemistry, edn. 2, Elsevier, Oxford, UK, p. 83, 2006.

Genovese, C., Grotti, M., Pittaluga, J., Ardini, F., Janssens, J., Wuttig, K., Moreau, S., and Lannuzel, D.: Influence of organic complexation on dissolved iron distribution in East Antarctic pack ice, Mar. Chem., 203, 28-37, https://doi.org/10.1016/j.marchem.2018.04.005, 2018.

Gerringa, L. J. A., Blain, S., Laan, P., Sarthou, G., Veldhuis, M. J. W., Brussaard, C. P. D., Viollier, E., and Timmermans, K. R.: Fe-binding dissolved organic ligands near the Kerguelen Archipelago in the Southern Ocean (Indian sector), Deep-Sea Res. Pt. II, 55, 606-621, https://doi.org/10.1016/j.dsr2.2007.12.007, 2008.

Gerringa, L. J. A., Rijkenberg, M. J., Thuróczy, C.-E., and Maas, L. R.: A critical look at the calculation of the binding characteristics and concentration of iron complexing ligands in seawater with suggested improvements, Environ. Chem., 11, 114-136, https://doi.org/10.1071/EN13072, 2014.

Gerringa, L. J. A., Rijkenberg, M. J. A., Schoemann, V., Laan, P., and de Baar, H. J. W.: Organic complexation of iron in the West Atlantic Ocean, Mar. Chem., 177, 434-446, https://doi.org/10.1016/j.marchem.2015.04.007, 2015.

Gerringa, L. J. A., Laan, P., Arrigo, K., van Dijken, G., and Alderkamp, A.-C.: The organic complexation of iron in the Ross sea, Mar. Chem., 215, 103672, https://doi.org/10.1016/j.marchem.2019.103672, 2019.

Gerringa, L. J. A., Gledhill, M., Ardiningsih, I., Muntjewerf, N., and Laglera, L. M.: Comparing CLE-AdCSV applications using $\mathrm{SA}$ and TAC to determine the Fe binding characteristics of model ligands in seawater, Biogeosciences, in review, 2021.

Gledhill, M. and Buck, K.: The organic complexation of iron in the marine environment: A review, Front. Microbiol., 3, 69, https://doi.org/10.3389/fmicb.2012.00069, 2012.

Gledhill, M. and Gerringa, L. J. A.: The Effect of Metal Concentration on the Parameters Derived from Complexometric Titrations of Trace Elements in Seawater - A Model Study, Frontiers in Marine Science, 4, 254, https://doi.org/10.3389/fmars.2017.00254, 2017

Grotov, A. S., Nechaev, D. A., Panteleev, G. G., and Yaremchuk, M. I.: Large scale circulation in the Bellingshausen and Amundsen seas as a variational inverse of climato- logical data, J. Geophys. Res.-Oceans, 103, 13011-13022, https://doi.org/10.1029/98jc00449, 1998.

Hassler, C., Cabanes, D., Blanco-Ameijeiras, S., Sander, S. G., and Benner, R.: Importance of refractory ligands and their photodegradation for iron oceanic inventories and cycling, Mar. Freshwater Res., 71, 311-320, https://doi.org/10.1071/MF19213, 2020.

Hassler, C. S., van den Berg, C. M. G., and Boyd, P. W.: Toward a Regional Classification to Provide a More Inclusive Examination of the Ocean Biogeochemistry of Iron-Binding Ligands, Frontiers in Marine Science, 4, 19 , https://doi.org/10.3389/fmars.2017.00019, 2017.

Henley, S. F., Schofield, O. M., Hendry, K. R., Schloss, I. R., Steinberg, D. K., Moffat, C., Peck, L. S., Costa, D. P., Bakker, D. C. E., Hughes, C., Rozema, P. D., Ducklow, H. W., Abele, D., Stefels, J., Van Leeuwe, M. A., Brussaard, C. P. D., Buma, A. G. J., Kohut, J., Sahade, R., Friedlaender, A. S., Stammerjohn, S. E., Venables, H. J., and Meredith, M. P.: Variability and change in the west Antarctic Peninsula marine system: Research priorities and opportunities, Prog. Oceanogr., 173, 208237, https://doi.org/10.1016/j.pocean.2019.03.003, 2019.

Hofmann, E. E. and Klinck, J. M.: Thermohaline variability of the waters overlying the west Antarctic Peninsula continental shelf, Ocean, Ice, and Atmosphere: Interactions at the Antarctic Continental Margin, Antarct. Res. Ser, 75, 67-81, https://doi.org/10.1029/AR075p0067, 1998.

Joy-Warren, H. L., van Dijken, G. L., Alderkamp, A.-C., Leventer, A., Lewis, K. M., Selz, V., Lowry, K. E., van de Poll, W., and Arrigo, K. R.: Light Is the Primary Driver of Early Season Phytoplankton Production Along the Western Antarctic Peninsula, J. Geophys. Res.-Oceans, 124, 7375-7399, https://doi.org/10.1029/2019jc015295, 2019.

Klinck, J. M., Hofmann, E. E., Beardsley, R. C., Salihoglu, B., and Howard, S.: Water-mass properties and circulation on the west Antarctic Peninsula Continental Shelf in Austral Fall and Winter 2001, Deep-Sea Res. Pt. II, 51, 1925-1946, https://doi.org/10.1016/j.dsr2.2004.08.001, 2004.

Klunder, M. B., Laan, P., Middag, R., De Baar, H. J. W., and van Ooijen, J. C.: Dissolved iron in the Southern Ocean (Atlantic sector), Deep-Sea Res. Pt. II, 58, 2678-2694, https://doi.org/10.1016/j.dsr2.2010.10.042, 2011.

Krachler, R., Krachler, R. F., Wallner, G., Hann, S., Laux, M., Cervantes Recalde, M. F., Jirsa, F., Neubauer, E., von der Kammer, F., Hofmann, T., and Keppler, B. K.: River-derived humic substances as iron chelators in seawater, Mar. Chem., 174, 85-93, https://doi.org/10.1016/j.marchem.2015.05.009, 2015.

Kuma, K., Nishioka, J., and Matsunaga, K.: Controls on iron(III) hydroxide solubility in seawater: The influence of $\mathrm{pH}$ and natural organic chelators, Limnol. Oceanogr., 41, 396-407, https://doi.org/10.4319/lo.1996.41.3.0396, 1996.

Laglera, L. M., Sukekava, C. F., Slagter, H. A., Downes, J., Aparicio-Gonzalez, A., and Gerringa, L. J.: First Quantification of the Controlling Role of Humic Substances in the Transport of Iron Across the Surface of the Arctic Ocean, Environ. Sci. Technol., 53, 13136-13145, https://doi.org/10.1021/acs.est.9b04240, 2019a.

Laglera, L. M., Tovar-Sanchez, A., Sukekava, C. F., Naik, H., Naqvi, S. W. A., and Wolf-Gladrow, D. A.: Iron organic speciation during the LOHAFEX experiment: Iron ligands release un- 
der biomass control by copepod grazing, J. Marine Syst., 103151, 207, https://doi.org/10.1016/j.jmarsys.2019.02.002, 2019b.

Lam, P. J., Doney, S. C., and Bishop, J. K. B.: The dynamic ocean biological pump: Insights from a global compilation of particulate organic carbon, $\mathrm{CaCO}_{3}$, and opal concentration profiles from the mesopelagic, Global Biogeochem. Cy., 25, 3, https://doi.org/10.1029/2010gb003868, 2011.

Lannuzel, D., Grotti, M., Abelmoschi, M. L., and van der Merwe, P.: Organic ligands control the concentrations of dissolved iron in Antarctic sea ice, Mar. Chem., 174, 120-130, https://doi.org/10.1016/j.marchem.2015.05.005, 2015.

Lannuzel, D., Vancoppenolle, M., van der Merwe, P., de Jong, J. T. M., Meiners, K. M., Grotti, M., Nishioka, J., and Schoemann, V.: Iron in sea ice: Review and new insights, Elementa, 4, 000130, https://doi.org/10.12952/journal.elementa.000130, 2016.

Lauderdale, J. M., Braakman, R., Forget, G., Dutkiewicz, S., and Follows, M. J.: Microbial feedbacks optimize ocean iron availability, P. Natl. Acad. Sci. USA, 117, 4842-4849, https://doi.org/10.1073/pnas.1917277117, 2020.

Le Quéré, C., Andrew, R. M., Canadell, J. G., Sitch, S., Korsbakken, J. I., Peters, G. P., Manning, A. C., Boden, T. A., Tans, P. P., Houghton, R. A., Keeling, R. F., Alin, S., Andrews, O. D., Anthoni, P., Barbero, L., Bopp, L., Chevallier, F., Chini, L. P., Ciais, P., Currie, K., Delire, C., Doney, S. C., Friedlingstein, P., Gkritzalis, T., Harris, I., Hauck, J., Haverd, V., Hoppema, M., Klein Goldewijk, K., Jain, A. K., Kato, E., Körtzinger, A., Landschützer, P., Lefèvre, N., Lenton, A., Lienert, S., Lombardozzi, D., Melton, J. R., Metzl, N., Millero, F., Monteiro, P. M. S., Munro, D. R., Nabel, J. E. M. S., Nakaoka, S., O’Brien, K., Olsen, A., Omar, A. M., Ono, T., Pierrot, D., Poulter, B., Rödenbeck, C., Salisbury, J., Schuster, U., Schwinger, J., Séférian, R., Skjelvan, I., Stocker, B. D., Sutton, A. J., Takahashi, T., Tian, H., Tilbrook, B., van der Laan-Luijkx, I. T., van der Werf, G. R., Viovy, N., Walker, A. P., Wiltshire, A. J., and Zaehle, S.: Global Carbon Budget 2016, Earth Syst. Sci. Data, 8, 605-649, https://doi.org/10.5194/essd-8-605-2016, 2016.

Lin, H. and Twining, B. S.: Chemical speciation of iron in Antarctic waters surrounding free-drifting icebergs, Mar. Chem., 128-129, 81-91, https://doi.org/10.1016/j.marchem.2011.10.005, 2012.

Liu, X. and Millero, F. J.: The solubility of iron hydroxide in sodium chloride solutions, Geochim. Cosmochim. Ac., 63, 3487-3497, https://doi.org/10.1016/S0016-7037(99)00270-7, 1999.

Liu, X. and Millero, F. J.: The solubility of iron in seawater, Mar. Chem., 77, 43-54, https://doi.org/10.1016/S03044203(01)00074-3, 2002.

Macrellis, H. M., Trick, C. G., Rue, E. L., Smith, G., and Bruland, K. W.: Collection and detection of natural iron-binding ligands from seawater, Mar. Chem., 76, 175-187, 2001.

Maldonado, M. T., Strzepek, R. F., Sander, S., and Boyd, P. W.: Acquisition of iron bound to strong organic complexes, with different Fe binding groups and photochemical reactivities, by plankton communities in Fe-limited subantarctic waters, Global Biogeochem. Cy., 19, 4, https://doi.org/10.1029/2005GB002481, 2005.

Martin, J. H., Gordon, M., and Fitzwater, S. E.: The case for iron, 36, Limnol. Oceanogr., 1793-1802, https://doi.org/10.4319/lo.1991.36.8.1793, 1991.

Mawji, E., Gledhill, M., Milton, J. A., Tarran, G. A., Ussher, S., Thompson, A., Wolff, G. A., Worsfold, P. J., and Achterberg,
E. P.: Hydroxamate Siderophores: Occurrence and Importance in the Atlantic Ocean, Environ. Sci. Technol., 42, 8675-8680, https://doi.org/10.1021/es801884r, 2008.

Middag, R., De Baar, H., Laan, P., and Bakker, K.: Dissolved aluminium and the silicon cycle in the Arctic Ocean, Mar. Chem., 115, 176-195, https://doi.org/10.1016/j.marchem.2009.08.002, 2009.

Middag, R., de Baar, H. J. W., Klunder, M. B., and Laan, P.: Fluxes of dissolved aluminum and manganese to the Weddell Sea and indications for manganese co-limitation, Limnol. Oceanogr., 58, 287-300, https://doi.org/10.4319/lo.2013.58.1.0287, 2013.

Middag, R., de Baar, H. J. W., Bruland, K. W., and van Heuven, S. M. A. C.: The Distribution of Nickel in the West-Atlantic Ocean, Its Relationship With Phosphate and a Comparison to Cadmium and Zinc, Frontiers in Marine Science, 7, 105, https://doi.org/10.3389/fmars.2020.00105, 2020.

Mikaloff Fletcher, S., Gruber, N., Jacobson, A. R., Doney, S., Dutkiewicz, S., Gerber, M., Follows, M., Joos, F., Lindsay, K., and Menemenlis, D.: Inverse estimates of anthropogenic $\mathrm{CO}_{2}$ uptake, transport, and storage by the ocean, Global Biogeochem. Cy., 20, 2, https://doi.org/10.1029/2005GB002530, 2006.

Moffat, C. and Meredith, M.: Shelf-ocean exchange and hydrography west of the Antarctic Peninsula: a review, Philos. T. Roy. Soc. A, 376, 20170164, https://doi.org/10.1098/rsta.2017.0164, 2018.

Moore, C. M., Mills, M. M., Arrigo, K. R., Berman-Frank, I., Bopp, L., Boyd, P. W., Galbraith, E. D., Geider, R. J., Guieu, C., Jaccard, S. L., Jickells, T. D., La Roche, J., Lenton, T. M., Mahowald, N. M., Maranon, E., Marinov, I., Moore, J. K., Nakatsuka, T., Oschlies, A., Saito, M. A., Thingstad, T. F., Tsuda, A., and Ulloa, O.: Processes and patterns of oceanic nutrient limitation, Nat. Geosci., 6, 701-710, https://doi.org/10.1038/ngeo1765, 2013.

Mopper, K., Kieber, D. J., and Stubbins, A.: Marine Photochemistry of Organic Matter: Processes and Impacts, in: Biogeochemistry of Marine Dissolved Organic Matter, edn. 2, edited by: Hansell, D. A. and Carlson, C. A., Academic Press, Boston, Massachusetts, USA, 389-450, 2015.

Nolting, R. F., Gerringa, L. J. A., Swagerman, M. J. W., Timmermans, K. R., and de Baar, H. J. W.: Fe(III) speciation in the high nutrient, low chlorophyll Pacific region of the Southern Ocean, Mar. Chem., 62, 335-352, https://doi.org/10.1016/S0304-4203(98)00046-2, 1998.

Norman, L., Thomas, D. N., Stedmon, C. A., Granskog, M. A., Papadimitriou, S., Krapp, R. H., Meiners, K. M., Lannuzel, D., van der Merwe, P., and Dieckmann, G. S.: The characteristics of dissolved organic matter (DOM) and chromophoric dissolved organic matter (CDOM) in Antarctic sea ice, Deep-Sea Res. Pt. II, 58, 1075-1091, https://doi.org/10.1016/j.dsr2.2010.10.030, 2011.

Norman, L., Worms, I. A. M., Angles, E., Bowie, A. R., Nichols, C. M., Ninh Pham, A., Slaveykova, V. I., Townsend, A. T., David Waite, T., and Hassler, C. S.: The role of bacterial and algal exopolymeric substances in iron chemistry, Mar. Chem., 173 148-161, https://doi.org/10.1016/j.marchem.2015.03.015, 2015.

Orsi, A. H., Whitworth, T., and Nowlin, W. D.: On the meridional extent and fronts of the Antarctic Circumpolar Current, Deep-Sea Res. Pt. I, 42, 641-673, https://doi.org/10.1016/09670637(95)00021-W, 1995. 
Poorvin, L., Sander, S. G., Velasquez, I., Ibisanmi, E., LeCleir, G. R., and Wilhelm, S. W.: A comparison of Fe bioavailability and binding of a catecholate siderophore with virusmediated lysates from the marine bacterium Vibrio alginolyticus PWH3a, J. Exp. Mar. Biol. Ecol., 399, 43-47, https://doi.org/10.1016/j.jembe.2011.01.016, 2011.

Powell, R. T. and Wilson-Finelli, A.: Photochemical degradation of organic iron complexing ligands in seawater, Aquat. Sci., 65, 367-374, https://doi.org/10.1007/s00027-003-0679-0, 2003.

Raven, J. A. and Falkowski, P. G.: Oceanic sinks for atmospheric $\mathrm{CO}_{2}$, Plant Cell Environ., 22, 741-755, https://doi.org/10.1046/j.1365-3040.1999.00419.x, 1999.

Rijkenberg, M. J., Gerringa, L. J. A., Timmermans, K. R., Fischer, A. C., Kroon, K. J., Buma, A. G., Wolterbeek, B. T., and de Baar, H. J.: Enhancement of the reactive iron pool by marine diatoms, Mar. Chem., 109, 29-44, https://doi.org/10.1016/j.marchem.2007.12.001, 2008.

Saito, M. A. and Goepfert, T. J.: Zinc-cobalt colimitation of Phaeocystis antarctica, Limnol. Oceanogr., 53, 266-275, https://doi.org/10.4319/1o.2008.53.1.0266, 2008.

Saito, M. A., Goepfert, T. J., Noble, A. E., Bertrand, E. M., Sedwick, P. N., and DiTullio, G. R.: A seasonal study of dissolved cobalt in the Ross Sea, Antarctica: micronutrient behavior, absence of scavenging, and relationships with $\mathrm{Zn}, \mathrm{Cd}$, and P, Biogeosciences, 7, 4059-4082, https://doi.org/10.5194/bg-7-40592010, 2010.

Sato, M., Takeda, S., and Furuya, K.: Iron regeneration and organic iron(III)-binding ligand production during in situ zooplankton grazing experiment, Mar. Chem., 106, 471-488, https://doi.org/10.1016/j.marchem.2007.05.001, 2007.

Schoffman, H., Lis, H., Shaked, Y., and Keren, N.: Iron-Nutrient Interactions within Phytoplankton, Front. Plant Sci., 7, 1223, https://doi.org/10.3389/fpls.2016.01223, 2016.

Schofield, O., Saba, G., Coleman, K., Carvalho, F., Couto, N., Ducklow, H., Finkel, Z., Irwin, A., Kahl, A., Miles, T., MontesHugo, M., Stammerjohn, S., and Waite, N.: Decadal variability in coastal phytoplankton community composition in a changing West Antarctic Peninsula, Deep-Sea Res. Pt. I, 124, 42-54, https://doi.org/10.1016/j.dsr.2017.04.014, 2017.

Seyitmuhammedov, K., Stirling, C. H., Reid, M. R., van Hale, R., Laan, P., Arrigo, K. R., van Dijken, G., Alderkamp, A.-C., and Middag, R.: The distribution of Fe across the shelf of the Western Antarctic Peninsula at the start of the phytoplankton growing season, Mar. Chem., in review., 2021.

Sherrell, R. M., Annett, A. L., Fitzsimmons, J. N., Roccanova, V. J., and Meredith, M. P.: A shallow bathtub ring of local sedimentary iron input maintains the Palmer Deep biological hotspot on the West Antarctic Peninsula shelf, Philos. T. Roy. Soc. A, 376, 20170171, https://doi.org/10.1098/rsta.2017.0171, 2018.

Slagter, H. A., Gerringa, L. J. A., and Brussaard, C. P. D.: Phytoplankton Virus Production Negatively Affected by Iron Limitation, Frontiers in Marine Science, 3, 156, https://doi.org/10.3389/fmars.2016.00156, 2016.

Slagter, H. A., Reader, H. E., Rijkenberg, M. J. A., Rutgers van der Loeff, M., de Baar, H. J. W., and Gerringa, L. J. A.: Organic Fe speciation in the Eurasian Basins of the Arctic Ocean and its relation to terrestrial DOM, Mar. Chem., 197, 1125, https://doi.org/10.1016/j.marchem.2017.10.005, 2017.
Smith, D. A., Hofmann, E. E., Klinck, J. M., and Lascara, C. M.: Hydrography and circulation of the West Antarctic Peninsula Continental Shelf, Deep-Sea Res. Pt. I, 46, 925-949, https://doi.org/10.1016/S0967-0637(98)00103-4, 1999.

Stammerjohn, S., Massom, R., Rind, D., and Martinson, D.: Regions of rapid sea ice change: An inter-hemispheric seasonal comparison, Geophys. Res. Lett., 39, L06501, https://doi.org/10.1029/2012GL050874, 2012.

Sunda, W. G.: Trace metal interactions with marine phytoplankton, Biological Oceanography, 6, 411-442, https://doi.org/10.1080/01965581.1988.10749543, 1989.

Takeda, S.: Influence of iron availability on nutrient consumption ratio of diatoms in oceanic waters, Nature, 393, 774-777, https://doi.org/10.1038/31674, 1998.

Thuróczy, C.-E., Gerringa, L. J. A., Klunder, M. B., Laan, P., and de Baar, H. J. W.: Observation of consistent trends in the organic complexation of dissolved iron in the Atlantic sector of the Southern Ocean, Deep-Sea Res. Pt. II, 58, 2695-2706, https://doi.org/10.1016/j.dsr2.2011.01.002, 2011.

Thuróczy, C.-E., Alderkamp, A.-C., Laan, P., Gerringa, L. J. A., Mills, M. M., Van Dijken, G. L., De Baar, H. J. W., and Arrigo, K. R.: Key role of organic complexation of iron in sustaining phytoplankton blooms in the Pine Island and Amundsen Polynyas (Southern Ocean), Deep-Sea Res. Pt. II, 71-76, 49-60, https://doi.org/10.1016/j.dsr2.2012.03.009, 2012.

Tomczak, M. and Godfrey, J.: Regional oceanography: An introduction, Daya, New Delhi, India, Daya Publishing House, xi+390p, https://doi.org/10.1016/C2009-0-14825-0, 2003.

Turner, J., Maksym, T., Phillips, T., Marshall, G. J., and Meredith, M. P.: The impact of changes in sea ice advance on the large winter warming on the western Antarctic Peninsula, Int. J. Climatol., 33, 852-861, https://doi.org/10.1002/joc.3474, 2013.

Turner, J., Marshall, G. J., Clem, K., Colwell, S., Phillips, T., and Lu, H.: Antarctic temperature variability and change from station data, Int. J. Climatol., 40, 2986-3007, https://doi.org/10.1002/joc.6378, 2020.

Twining, B. S., Baines, S. B., and Fisher, N. S.: Element stoichiometries of individual plankton cells collected during the Southern Ocean Iron Experiment (SOFeX), Limnol. Oceanogr., 49, 2115 2128, https://doi.org/10.4319/lo.2004.49.6.2115, 2004.

Velasquez, I., Nunn, B. L., Ibisanmi, E., Goodlett, D. R., Hunter, K. A., and Sander, S. G.: Detection of hydroxamate siderophores in coastal and Sub-Antarctic waters off the South Eastern Coast of New Zealand, Mar. Chem., 126, 97-107, https://doi.org/10.1016/j.marchem.2011.04.003, 2011.

Velasquez, I. B., Ibisanmi, E., Maas, E. W., Boyd, P. W., Nodder, S., and Sander, S. G.: Ferrioxamine siderophores detected amongst iron binding ligands produced during the remineralization of marine particles, Frontiers in Marine Science, 3, 172, https://doi.org/10.3389/fmars.2016.00172, 2016.

Viljoen, J. J., Philibert, R., Van Horsten, N., Mtshali, T., Roychoudhury, A. N., Thomalla, S., and Fietz, S.: Phytoplankton response in growth, photophysiology and community structure to iron and light in the Polar Frontal Zone and Antarctic waters, Deep-Sea Res. Pt. I, 141, 118-129, https://doi.org/10.1016/j.dsr.2018.09.006, 2018. 
Whitby, H., Planquette, H., Cassar, N., Bucciarelli, E., Osburn, C. L., Janssen, D. J., Cullen, J. T., González, A. G., Völker, C., and Sarthou, G.: A call for refining the role of humic-like substances in the oceanic iron cycle, Sci. Rep.-UK, 10, 6144-6144, https://doi.org/10.1038/s41598-020-62266-7, 2020.

Wu, M., McCain, J. S. P., Rowland, E., Middag, R., Sandgren, M., Allen, A. E., and Bertrand, E. M.: Manganese and iron deficiency in Southern Ocean Phaeocystis antarctica populations revealed through taxon-specific protein indicators, Nat. Commun., 10, 3582, https://doi.org/10.1038/s41467-019-11426-z, 2019.

Ye, Y., Völker, C., and Gledhill, M.: Exploring the Iron-Binding Potential of the Ocean Using a Combined $\mathrm{pH}$ and DOC Parameterization, Global Biogeochem. Cy., 34, e2019GB006425, https://doi.org/10.1029/2019GB006425, 2020. 